\title{
CORRELATION STUDY OF CHEMOPHOBIA WITH SCIENCE LITERATURE
}

\author{
Nina Herlina ${ }^{1}$, Atik Ramawati ${ }^{2 *}$ \\ ${ }^{1}$ Student Majoring in Chemistry Education \\ Walisongo State Islamic University \\ ${ }^{2}$ Teaching Staff of The Chemistry Education Study Program \\ Walisongo State Islamic University \\ Walisongo Street No. 3-5 Tambakaji, Semarang, East Java. 50185 \\ *E-mail: atik_rahmawati@walisongo.ac.id
}

\begin{abstract}
Chemophobia is an irrational fear and anxiety of chemicals or chemicals. Many factors are the cause of chemophobia in addition to the wrong perception in understanding the meaning of the word chemistry itself, one of which is scientific knowledge or scientific literacy (scientific literacy) and many other factors. This study aims to examine the correlation of chemophobia with scientific literacy of students of the 2017 chemistry education study program at UIN Walisongo Semarang. This research is a type of quantitative research using a correlational approach. Participants were taken using a purposive sampling technique, the selection of participants was based on the objectives of the researcher, namely the 2017 class of chemistry education students as many as 27 students. The data sources come from the chemophobia questionnaire and scientific literacy test questions. The Cronbach's Alpha method was used to test the reliability of the questionnaires and questions of scientific literacy, obtained a reliability value of 0.673 for the chemophobia questionnaire and 0.719 for scientific literacy questions. The research data were analyzed using Speaman Rank correlation with the help of IBM SPSS 25 . The results of data analysis showed a correlation value (r) -0.232 a negative sign contained in the correlation value indicated that there was a relationship between the two variables that were not unidirectional, but the sig value. The number $0.244>0.05$, it can be concluded that there is no significant relationship between chemophobia and scientific literacy.
\end{abstract}

Keywords: chemophobia, scientific literacy, UIN Walisongo Semarang

\section{INTRODUCTION}

I

n everyday life chemistry or chemicals have many benefits. Especially in the modern era like in the $21^{\text {st }}$ century. Synthetic chemicals have an important role, it is unimaginable what life in the $21^{\text {st }}$ century would be like without synthetic chemicals (Etine, 2011). The life of modern society cannot be separated from chemicals, because basically human activities are chemical activities. Starting from eating, drinking, bathing, washing dishes, even before going to bed can't be separated from chemicals (Fananta et al., 2018). This is what makes humans unable to avoid using chemicals in everyday life.

In fact, very few are aware that chemicals are indispensable in the manufacture of everyday goods. This is because the products people buy such as cell phones, cars, and processed foods seem far from raw chemicals (Siegrist \& Bearth, 2019). Common people's perceptions of chemicals tend to be negative in general based on 
misunderstanding and fear. A growing illusion is that chemicals can be categorized into "safe" versus "unsafe" chemicals (Etine, 2011). The majority of people view natural chemicals as better and safer than synthetic chemicals (Saleh et al., 2019). This unreasonable (irrationalfear) of chemicals is called chemophobia (Etine, 2011; Gribble, 2013).

Chemophobia is a cultural phenomenon that has only recently been identified (Crowe, 2019). Chemophobia is defined as a fear of chemicals, which can even cause the person to avoid products containing chemicals (Entine, 2011; Bumbac et al., 2018; Chalupa \& Nesměrák, 2019; Saleh et al., 2020;) such as in food, drugs, vaccines and other products related to chemicals (Crowe, 2019). Chemophobia also has the idea that chemistry is synonymous with poison and is not natural (Francl, 2013; Ibrahim \& Iksan, 2018). In fact, chemicals can be found anywhere. Chemistry or chemicals make up all life from humans, plants, animals, rocks, cars, to air, all of which are composed of chemical compounds. Chemicals are also found in immovable parts of the environment and even in natural products that are essential for human health and quality of life.

Excessive fear of everything related to chemistry is found quite widely in the Western world as well as Asia (Gribble, 2013). Including in Indonesia, as research conducted by Hamid (2018) on people in the Yogyakarta area found chemophobia. Chemophobia is even still found in students, as research has been done by Herlina et al. (2020) should Chemophobia no longer be identified, considering that the respondent's background is already at the student level.

The roots of chemophobia are believed to have existed since the time of Ibn Sina, which was around $980 \mathrm{M}-1037 \mathrm{M}$ People at that time had rejected anything related to imitation. Like the principle of Ibn Sina which says:

"whatever God created through natural powers cannot be imitated artificially; human industry is not the same as what nature does."

which means: whatever God has created through the power of nature cannot be artificially imitated (artificial), what humans make is not the same as what nature produces (Chalupa \& Nesměrák, 2018).

This shows that people at that time had preceded people today who believed that vitamin $\mathrm{C}$ in citrus fruits would be different from vitamin $\mathrm{C}$ produced by synthetic means (Chalupa \& Nesměrák, 2018). Furthermore, people tend to believe that whatever is produced by human intervention cannot be the same as that which comes from nature (Saleh et al., 2020). A common mistake that occurs is to believe that natural (organic) foods are inherently safer than synthetics (Gribble, 2013). Misunderstanding the word "organic" is another effect caused by the fear of chemicals which actually refers to the word organic, which refers to cultivation techniques, not the nutritional content of a substance. A person who has been obsessed with pure (natural) food believes that something that Allah (or nature) has created is designed well for him (Entine, 2011). As has been the case today, most manufacturers label their products with organic or even chemical-free labels to attract consumers' interest.

Chemicals are believed to be the cause of environmental pollution (Berdonosov et al., 1999) and a source of environmental problems such as the problem of plastic pollution in the oceans, ozone depletion, and global warming (Bumbac et al., 2018). Chemicals themselves are often associated with cancer, toxicity and death. A popular belief is that herbal medicines are completely safe (Chalupa \& Nesměrák, 2018). The unrealistic expectation that drugs (and all chemicals) should be risk-free and sometimes leads to 
drugs that have a benefit are no longer on the market. Until now, mindset the ingrainedis that the risks generated by nature are not so threatening and will not be the same as the risks generated by humans (synthetic).

This rhetoric suggests that substances that sound synthetic or chemical are inherently more dangerous than substances that claim to be natural (Crowe, 2019). In fact, that a substance is natural does not mean automatically harmless to humans (Bumbac et al., 2018). The potential danger or not of a substance, does not depend on natural or synthetic. All chemicals, both synthetic and natural, have the potential to cause harm to humans in certain situations. There are no non-toxic chemicals, only certain types and levels of exposure can have an effect (depending on the dose) (Etine, 2011; Gribble, 2013). As is the case if consuming food or even vitamins can be dangerous if you consume them in large quantities. Therefore, giving a bad and dangerous label or being toxic to all chemicals is not possible, but the benefits of these chemicals must also be considered.

Generally, lay people rely on at least three rules of thumb in evaluating chemicals, namely, the heuristics "natural is better", "contagion" and "trust". Lack of knowledge and relying solely on simple heuristics may cause discomfort and even fear of synthetic chemicals in the environment (Siegrist \& Bearth, 2019a). Thus, lack of knowledge is the reason for the negative perception of chemicals (Bearth et al., 2014; Lee et al., 2019; Siegrist \& Bearth, 2019a). Based on the results of research conducted by Herlina et al. (2020) said knowledge is one of the factors that influence chemophobia.

A good view of an object is due to a person's good understanding of an object. Siegrist \& Bearth (2019a) also stated that relevant knowledge is an important factor in reducing chemophobia, respondents who were not informed about chemistry were unable to remember the concrete applications or benefits of chemicals. Therefore, knowledge is very influential in shaping the perception of chemicals. According to Chalupa \& Nesměrák (2018), a person's understanding of science will have an impact on his understanding of the world. This causes knowledge about science or science is very necessary so that there are no misunderstandings about chemical.

According to Deboer (2000), scientific literacy is useful for providing a broad understanding of science, regardless of whether someone will become a scientist or not. Morais (2015) also said that it is necessary to prepare the younger generation with good scientific and technological literacy. Therefore, each individual must possess scientific and technological knowledge that enables understanding of important world phenomena and participation in democratic decision-making from a shared responsibility perspective. What's more, in the $21^{\text {st }}$ century scientific literacy is one of the necessary skills and a demand of the times. According to Rahayu (2017), a scientifically literate society is a society that has knowledge of scientific facts and the relationship between science, technology and society and is also able to apply their knowledge to solve real-life problems.

Chemistry is also included in the science family. Therefore, chemical literacy is also part of scientific literacy (Sujana, 2014). Chemical literacy here refers to a person's ability to understand and apply chemical knowledge in everyday life. According to Lin (as quoted in Sujana, 2014) scientific literacy makes a person understand reports, discuss chemistry and chemicals and overcome various kinds of environmental issues in everyday life. Crowe (2019) said that overall scientific literacy could increase if people understood more about safe and unsafe chemicals.

Various studies conducted by Armas et al. (2019) showed that there was a relationship between scientific literacy and student achievement. The same thing was also 
explained by El Islami et al. (2015) which showed that there was no significant relationship between scientific literacy and students' self-confidence. So far, there is not much information that provides data on the relationship between scientific literacy and chemophobia, so this research is a new research that is also important to do.

Based on the background of the problem, the researcher wants to conduct research on the correlation between chemophobia and scientific literacy in the chemical education study program of UIN Walisongo Semarang. The purpose of this study was to examine how the correlation of chemophobia with scientific literacy of students of the 2017 chemistry education study program at UIN Walisongo Semarang. After knowing the category of chemophobia they have, as prospective chemistry educators are expected to be able to find effective learning methods and can also stimulate students to actively think and relate chemistry to their daily lives by emphasizing the importance of chemistry, it will open students' minds about the importance of chemistry for learning. change the mindset of students towards chemistry so that later their students will not experience chemophobia.

\section{RESEARCH METHODS}

This research is a type of quantitative research using a correlational approach. This research is a type of quantitative research because the research data obtained are in the form of numbers and the analysis uses statistics (Sugiyono, 2015). Correlational research is research that aims to determine whether or not there is a relationship between two or several variables in a study group of objects. This study aims to see the relationship between chemophobia and scientific literacy skills.

Samples were taken using a non- probability sampling technique, namely purposive sample. The purposive samplesampling technique is atechnique with certain considerations (Sugiyono, 2017). The samples used here are students of the 2017 chemistry education study program at UIN Walisongo Semarang. The sample was chosen because it was considered to have more knowledge and understanding of chemistry.

The data collection technique used in this study used a questionnaire method and a test instrument. Thescale chemophobia used is an instrument that has been developed by Saleh et al. (2019). Meanwhile, the scientific literacy instrument used was adopted from the OECD'S PISA questions. Analysis of research data in the form of categorizing chemophobia, and categorizing scientific literacy and hypothesis testing using thecorrelation test Spearman Rank. The hypothesis testing uses Spearman Rank because the number of respondents is less than the criteria (50 people) so it does not meet the parametric test.

\section{RESULTS AND DISCUSSION}

The results of statistical analysis of scores chemophobia of chemical education students at UIN Walisongo Semarang are presented in Table 1. The average score of chemophobia respondents is 16.22 from the ideal score that can be obtained, which is 3.86. This figure shows that overall chemistry education students class 2017 UIN Walisongo Semarang have $46.35 \%$ anxiety of the highest anxiety (100\%) they can have. The determination of thescale category chemophobia in this study is divided into five categories, namely; very low, low, medium, high, very high. The number of statement items is 7 statements with 5 answer choices, strongly agree, agree, doubt, disagree, and strongly disagree. 
Table 1. Statistics of chemophobia

\begin{tabular}{ll}
\hline Statistics & Score \\
\hline Number of samples & 27 \\
Average & 16,22 \\
Minimum score & 8 \\
Maximum score & 24 \\
Variance & 14.87 \\
Standard deviation & 3.86 \\
\hline
\end{tabular}

Table 2. Categories of chemophobia

\begin{tabular}{llll}
\hline Score & Frequency & Percentage & Category \\
\hline $\mathbf{X}<\mathbf{2 9 , 8 2}$ & 2 & $7,41 \%$ & Very low \\
$\mathbf{2 9 , 8 2}<\mathbf{X} \leq \mathbf{4 0 , 8 4}$ & 8 & $29,63 \%$ & Low \\
$\mathbf{4 0 , 8 4}<\mathbf{X} \leq \mathbf{5 1 , 8 6}$ & 9 & $33,33 \%$ & Medium \\
$\mathbf{5 1 , 8 6}<\mathbf{X} \leq \mathbf{6 2 , 8 8}$ & 6 & $22,22 \%$ & High \\
$\mathbf{X}>\mathbf{6 2 , 8 8}$ & 2 & $7,41 \%$ & Very high \\
\hline
\end{tabular}

Based on the results of determining the categories in the table above, it can be said that there are 2 people $(7.41 \%)$ very low anxiety category, 8 people $(29.63 \%)$ low anxiety category, 9 people $(33.33 \%)$ moderate anxiety category, 6 people $(22.22 \%)$ in the high anxiety category, 2 people $(7.41 \%)$ in the very high anxiety category, so it can be concluded that the average scientific literacy score of the respondents is in the medium category.

Results of statistical analysis of scientific literacy scores chemical education students at UIN Walisongo Semarang are presented in Table 3.

Table 3. Statistics of scientific literacy

\begin{tabular}{ll}
\hline Statistics & Score \\
\hline Number of samples & 27 \\
Average & 57.22 \\
Minimum score & 41 \\
Maximum score & 70 \\
Variance & 60.33 \\
Standard deviation & 7.77 \\
\hline
\end{tabular}

Average score scientific literacy the respondent is $\mathbf{5 7 . 2 2}$ from the ideal score that can be obtained, which is 84 . This figure shows that overall chemistry education students of class 2017 UIN Walisongo Semarang have a scientific literacy score of $68.12 \%$ of the highest scientific literacy score $(100 \%)$ that can be owned. Determination of scientific literacy score categories in this study is divided into five categories, namely very low, low, medium, high, very high. The number of statement items is 14 essay questions.

Table 4. Categories of Scientific Literacy

\begin{tabular}{llll}
\hline Score & Frequency & Percentage & Category \\
\hline $\mathbf{X}<\mathbf{5 4 , 2 5}$ & 2 & $7.41 \%$ & Very low \\
$\mathbf{5 4 , 2 5}<\mathbf{X} \leq \mathbf{6 3 , 5 0}$ & 6 & $22.22 \%$ & Low \\
$\mathbf{6 3 , 5 0}<\mathbf{X} \leq \mathbf{7 2 , 7 5}$ & 7 & $25.93 \%$ & Medium \\
$\mathbf{7 2 , 7 5}<\mathbf{X} \leq \mathbf{8 1 , 9 9}$ & 11 & $40.74 \%$ & High \\
$\mathbf{X}>\mathbf{8 1 , 9 9}$ & 1 & $3.70 \%$ & Very high \\
\hline
\end{tabular}

Based on the results of determining the categories in the table above, it can be said that there are 2 people $(7.41 \%)$ in the category of very low scientific literacy ability, 6 people $(22.22 \%)$ with low scientific literacy ability category, 7 people $(25.93 \%)$ with 
moderate scientific literacy ability category, 11 people $(40.74 \%)$ with high scientific literacy ability category, 1 person $(3.70 \%)$ with very high scientific literacy ability category, so it can be concluded that the average scientific literacy score of respondents is in the category high.

In this study, researchers examined the correlation of chemophobia with scientific literacy of students of the 2017 chemistry education study program at UIN Walisongo Semarang. Testing the hypothesis used in analyzing the data using the rtest correlation by Spearman Rank with the help of software IBM SPSS 25. The results of hypothesis testing using correlation analysis can be seen in Table 5.

Table 5. Hypothesis test results

\begin{tabular}{|c|c|c|c|c|}
\hline \multicolumn{5}{|c|}{ Correlations } \\
\hline & & & Literacy & Chemophobia \\
\hline \multirow[t]{8}{*}{ Spearman's rho } & Literacy & Correlation & 1,000 &,- 232 \\
\hline & & Coefficient & & \\
\hline & & Sig. (2-tailed) & . & ,244 \\
\hline & & $\mathrm{N}$ & 27 & 27 \\
\hline & Chemophobia & Correlation &,- 232 & 1,000 \\
\hline & & Coefficient & & \\
\hline & & Sig. (2-tailed) & ,244 & \\
\hline & & $\mathrm{N}$ & 27 & 27 \\
\hline
\end{tabular}

Based on the results of the correlation test, the correlation coefficient value between chemophobia and scientific literacy is -0.232 This shows that the relationship between chemophobia and scientific literacy has a weak correlation, because the correlation is in the correlation coefficient interval 0.21-0.40 with the criteria weak correlation.

In the research that has been carried out, the coefficient value is -0.233 , a negative sign on the correlation coefficient value means that there is a - (negative) relationship between chemophobia and scientific literacy, which means that if the literacy variable is high then chemophobia is low, but the value is significant. obtained a value of 0.244> 0.05 , also whenvalue of $r_{\mathrm{s}}$ compared with ther value table Rank Spearman $r$ table values obtained were greater than $r_{s}$ with error level of $5 \%(0.05)$. The $r$ value of thetable Spearman Rank for respondent 27 is $0.323>-0.232$, so that H0 in this study is accepted or it can be concluded that there is no significant relationship between chemophobia and scientific literacy.

Chemophobia is an irrational fear of chemicals and chemicals. Chemophobia also makes a person hypersensitive or even intolerant and prevents them from realizing the importance of chemical knowledge (Chalupa \& Nesměrák, 2018) in everyday life. Lack of knowledge is one of the factors that causes the fear of chemistry (chemophobia) (Lee et al., 2019; Saleh et al., 2020; Siegrist \& Bearth, 2019). Based on the results of the analysis of research data described above, it can be seen that in general thechemophobia respondents'is in the moderate category with a percentage of $33.33 \%$ (9 students). The data chemophobia also shows differences in the level of anxiety between students, one with another.

The results of thecategory chemophobia can be said to be quite good considering chemophobia is an irrational (unreasonable) fear of chemistry, thus it can be said that the 2017 chemistry education students at UIN Walisongo Semarang did not experience significant chemophobia against chemistry. The results of determining the scientific literacy category of chemical education students class 2017 UIN Walisongo Semarang in general are also in the high category with a percentage of $40.74 \%$ (11 students). The 
majority of respondents already have a good knowledge of chemistry. This is because the respondent's background is from the department of chemistry education, so the chemophobia results of the respondents are not too high. In line with the theory of Lee et al. (2019) which says that unfounded fear of chemicals caused by a lack of comprehensive knowledge and information. Herlina et al. (2020) also said that the more one understands or has more knowledge of an object, the better that person's view of the object will be.

Testing the hypothesis using a non-parametric test, namely thetest Spearman Rank. According to Tyastirin \& Hidayati (2017), before determining to use parametric or nonparametric tests, an initial test can be carried out, namely the normality test. As for the normality test, the minimum number of samples is 50 , because the number of respondents is less than the criteria (50 people) for parametric testing. The results obtained from the test Spearman Rank obtained a significance value of -0.323 , which means that there is a relationship between chemophobia and the scientific literacy of chemistry education students. The correlation coefficient value is -0.323 indicating that there is a weak relationship between chemophobia and scientific literacy and there is a negative sign (-) which means that the relationship between the two variables is (opposite direction). This means that if scientific literacy increases then chemophobia decreases and vice versa if scientific literacy decreases then chemophobia increases, but thecorrelation test Spearman Rank obtained a sig value.0.244>0.05 we can conclude there is no meaningful or significant relationship between chemophobia with scientific literacy, many factors that caused this to happen, given Chemophobia an fear irrational of something related to chemistry (Etine 2011; Gribble, 2013 ) many other factors also cause Chemophobia such as age, gender (Siegrist \& Bearth, 2019a) media, public opinion and so on, which may be other factors that have more influence on chemophobia. Therefore, for the future researchers can research to find other factors that influence chemophobia.

\section{CONCLUSION}

Based on the research that has been done, it can be concluded that there is a relationship between chemophobia and scientific literacy with a relationship in the weak category. The correlation value is -0.232 The minus sign in the correlation value means that if scientific literacy increases then chemophobia decreases and vice versa if scientific literacy decreases then chemphobia 0.244 increases, but at significant values obtained a value of $>0.05$ and the value of $r_{s}$ is compared with the $r$ value of the Spearman Rank table, the value of the $r$ table is greater than the $r_{s}$ with an error rate of 5\% (0.05). The $r$ value of the table Spearman Rank for respondent 27 is $0.323>0.232$, so that the $\mathrm{H}_{0}$ in this study is accepted, it can be concluded that there is no significant relationship between chemophobia and scientific literacy.

\section{REFERENCES}

Anjarsari, P. (2014). Literasi sains dalam kurikulum dan pembelajaran IPA SMP. Prosiding Seminar Nasional "Peran Literasi Sains". Surabaya, 20 Desember 2014.

Arikunto. (2013). Prosedur Penelitian Suatu Pendekatan Praktik. Jakarta: PT Rineka Cipta.

Armas, A.R.K., Ramlawati., \& M. Syahrir. (2019). Hubungan antara literasi sains dengan prestasi belajar peserta didik pada pembelajaran kimia kelas XI MIPA SMA Negeri Se-Kota Makassar. Chemistry Education Review (CER), 2(2), 1-10. https://doi.org/10.26858/cer.v2i2.8950.

Arsyad, M., Sopandi, W., \& Chandra, D. T. (2016). Analisis literasi sains pada pelajaran IPA di Sekolah Menengah Pertama Se-Kota Bandung. Prosiding SNIPS 2016 . 21-22 Juli 2016.

Bearth, A., Cousin, M. E., \& Siegrist, M. (2014). The consumer's perception of artificial food additives: Influences on acceptance, risk and benefit perceptions. Food Quality and Preference, 38, 14-23. 
https://doi.org/10.1016/j.foodqual.2014.05.008.

Berdonosov, S. S., Kuzmenko, N. E., \& Kharisov, B. I. (1999). Experience in chemical education in russia: how to attract the young generation to chemistry under conditions of "chemophobia. Journal of Chemical Education, 76(8), 1086-1088. https://doi.org/10.1021/ed076p1086.

Bumbac, M., Nicolescu, C., Serban, B.-C., Buiu, O., Nicolescu, C.-M., \& Cobianu, C. (2018). Chemistrythe journey from central science to chemofobia; How should we address this? Journal of Science and Arts Year, 18(4), 1045-1060.

Chalupa, R., \& Nesmerak, K. (2018). Analytical chemistry as a tool for suppressing chemophobia: an introduction to the 5E-principle. Monatshefte für Chemie - Chemical Monthly, 149, 1527-1534. https://doi.org/10.1007/s00706-018-2224-9.

Chalupa, R., \& Nesměrák, K. (2019). Chelation as a metaphor for the effective fight against chemophobia. Monatshefte Fur Chemie, 150(9), 1585-1592. https://doi.org/10.1007/s00706-019-02453-z.

Crowe, J. M. (2019). Chemophobia and Relation Names. Florida: Jacksonville: Junior College Chemistry.

Deboer, G. E. (2000). Scientific literacy: Another look at its historical and contemporary meanings and its relationship to science education reform. Journal of Research in Science Teaching, 37(6), 582-601.

Eddy, R.M. (2000). Chemophobia in the college classroom: extent, sources, and student characteristics. Journal of Chemical Education, 77(4), 2-5.

Eivers, E., \& Kennedy, D. (2016). The PISA assessment of scientific literacy. The Irish Journal of Education, 37, 101-119.

Etine, J .(2004). Scared To Death: How Chemophobia Threatens Public Health. New York: American Council on Science and Health.

El Islami, Z. A. R., Nahadi., \& Permanasari, A. (2015). Hubungan literasi sains dan kepercayaan diri siswa pada konsep asam basa. Jurnal Penelitian dan Pembelajaran IPA, 1(1), 16-25.

Francl, M. (2013). How to counteract chemophobia. Nature Publishing Group, 5(6), 439-440. https://doi.org/10.1038/nchem.1661.

Gribble, G.W. (2013). Food chemistry and chemophobia. Food Security, 5(2), 177-187. https://doi.org/10.1007/s12571-013-0251-2.

Hamid, A. (2018). Analisis Persepsi Masyarakat terhadap Bahan Kimia. [Skripsi]. Yogyakarta: UIN Sunan Kalijaga.

Herlina, N., Pratiwi, R., \& Mulyanti, S. (2020). Identifikasi chemophobia dan faktor yang mempengaruhi persepsi pada mahasiswa. Journal of Educational Chemistry (JEC), 2(2), 73-82. https://doi.org/10.21580/jec.2020.2.2.6318.

Ibrahim, N.H.B., \& Hj. Iksan, Z. B. (2018). Level of chemophobia and relationship with attitude towards chemistry among science students. Journal of Educational Sciences, 2(2), 52-65. https://doi.org/10.31258/jes.2.2.p.52-65.

Kamaruddin, N., Ibrahim, N.H., Surif, J. (2015). Attribution Factors of Chemistry Anxiety: What are they?. $2^{\text {nd }}$ International Education Postgraduates Seminars. Johor Bahru, 20-21 December, 2015.

Lee, B. M., Kwon, S., Cho, Y. M., Kim, K. B., Seo, K., Min, C. S., \& Kim, K. (2019). Perspectives on trace chemical safety and chemophobia: risk communication and risk management. Journal of Toxicology and Environmental Health-Part A: Current Issues, 82(2), 113-127. https://doi.org/10.1080/ 15287394.2019.1567972.

Michaelis, A.R. (2013). Stop-chemophobia. Interdisiplinary Science Review, 21(2), 130-139. https://doi.org/10.1179/isr.1996.21.2.130.

Morais, C. (2015). Storytelling with Chemistry and Related Hands-On Activities: Informal Learning Experiences To Prevent "Chemophobia" and Promote Young Children's Scientific Literacy. Journal Chemical Education, 92(1), 58-65.

OECD. (2017). PISA 2015 Assessment and Analytical Framework Science, Reading, Mathematic, Financial Literacy And Collaborative Problem Solving. Paris: OECD.

OECD. (2009). PISA 2009 Assessment Framework Key competencies in Reading, Mathematics And Science. Paris: OECD.

OECD. (2000). Knowladge and Skill For Life. USA:OECD-PISA.

Prastiwi, M.N.B., N. Rahmah., N. Khayati., D.P. Utami., M. Primastuti., A.N. Majid. (2017). Studi kemampuan literasi kimia peserta didik pada materi elektrokimia. Prosiding Seminar Nasional Kimia UNY 2017. Yogyakarta, 14 Oktober 2017.

Rahayu, S. (2017). Mengoptimalkan aspek literasi dalam pembelajaran kimia abad 21. Prosiding Seminar Nasional Kimia UNY, 21(March), 1-16.

Saleh, R., Bearth, A., \& Siegrist, M. (2019). "Chemophobia" today: Consumers' knowledge and perceptions of chemicals. Risk Analysis, 39(12), 2668-2682. https://doi.org/10.1111/risa.13375. 
Saleh, R., Bearth, A., \& Siegrist, M. (2020). Addressing chemophobia: informational versus affect-based approaches. Food and Chemical Toxicology, 140(2020), 1-9. https://doi.org/10.1016/ j.fct.2020.111390.

Siegrist, M., \& Bearth, A. (2019a). Chemophobia in Europe and reasons for biased risk perceptions. Nature Chemistry, 11(12), 1071-1072. https://doi.org/10.1038/s41557-019-0377-8.

Sugiyono. 2016. Statistika Untuk Penelitian. Bandung: Alfabet.

Sugiyono. 2015. Metodologi Penelitian Pendekatan Kuantitatif, Kualitatif, dan R\&D. Bandung:Alfabeta.

Sugiyono. 2017. Metodologi Penelitian Pendidikan Pendekatan Kuantitatif, Kualitatif, dan R\&D. Bandung:Alfabeta.

Sujana, A. (2014). Literasi kimia mahasiswa PGSD dan guru IPA Sekolah Dasar pada tema udara. Mimbar Sekolah Dasar, 1(1), 99-107. https://doi.org/10.17509/mimbar-sd.v1i1.870.

Tyastirin, E. \& Hidayati, I. (2017). Statistik Parametrik Untuk Penelitian. Surabaya: Program Studi Arsitektur UIN Sunan Ampel

Widyoko, E.P, (2016). Teknik Penyusunan Instrumen Penelitian. Yogyakarta: Pustaka Pelajar.

Zainuddin, F.M \& Osman, K. (2014). Kebimbangan kimia dalam kalangan pelajar aliran sains di Sekolah Menengah Daerah Hulu Langat. Proceeding ICGE, 1384-1395. 